\title{
Protozooplankton and its relationship with environmental conditions in 13 water bodies of the Mogi-Guaçu basin - SP, Brazil
}

\author{
Inessa Lacativa Bagatini ${ }^{1,4}$, Ana Lúcia Gerardi Spínola ${ }^{1}$, Bianca de Miranda Peres ${ }^{1}$, \\ Adrislaine da Silva Mansano ${ }^{1}$, Mafalda Alexandra Antunes Rodrigues ${ }^{1}$, \\ Marco Antônio Portugal Luttembarck Batalha², José Valdecir de Lucca', \\ Mirna Januária Leal Godinho ${ }^{1}$, Takako Matsumura Tundisi ${ }^{3}$ \& Mirna Helena Regali Seleghim ${ }^{I}$ \\ ${ }^{1}$ Laboratório de Ecologia de Microrganismos Aquáticos, Departamento de Ecologia e Biologia Evolutiva, \\ Universidade Federal de São Carlos - UFSCar, Rod. Washington Luís, Km 235, CEP 13565-905, \\ São Carlos, SP, Brasil. http://www.ufscar.br \\ ${ }^{2}$ Departamento de Botânica, Universidade Federal de São Carlos - UFSCar, \\ Rod. Washington Luís, km 235, CEP 13565-905, São Carlos, SP, Brasil. http://www.ufscar.br \\ ${ }^{3}$ Instituto Internacional de Ecologia - IIE, Rua Bento Carlos, 750, CEP 13560-660, São Carlos, SP, Brasil. \\ http://www.iie.com.br/ \\ ${ }^{4}$ Corresponding author: Inessa Lacativa Bagatini, e-mail: inessalacativa@gmail.com
}

BAGATINI, I.L., SPÍNOLA, A.L.G., PERES, B.M., MANSANO, A.S., RODRIGUES, M.A.A., BATALHA, M.A., LUCCA, J.V., GODINHO, M.J.L., TUNDISI, T.M. \& SELEGHIM, M.H.R. Protozooplankton and its relationship with environmental conditions in 13 water bodies of the Mogi-Guaçu basin - SP, Brazil. Biota Neotrop. 13(4): http://www.biotaneotropica.org.br/v13n4/en/abstract?article+bn02913042013

\begin{abstract}
Protozooplankton is an important component of the aquatic microbial food webs and its composition, density, and distribution reflect the chemical, physical, and biological aspects of the environment. Considering the scarce literature on freshwater protozoans in Brazil and on protozoan ecology in subtropical environments, we listed the ciliates and amoebae taxa found in 13 water bodies in São Paulo State and analyzed their abundance in relation to the environmental variables. We collected two samples in each environment, fixed immediately with mercuric chloride and stained with bromophenol blue. After microscopical analysis, 74 protozoan genera were identified and the Ciliophora were dominant in the majority of the environments. The Stichotrichia, represented mostly by the genus Halteria, occurred in all environments, and was the dominant subclass in five of them. The canonic correspondence analysis of the most frequent genera and the environmental variables showed that nitrite and nitrate were the variables that better explained the distribution of Limnostrombidium, Urotricha, and Vorticella. The densities of the genera Halteria, Coleps, and of the species Cinetochilum margaritaceum were positively affected by increasing concentrations of dissolved oxygen, particulate phosphate, conductivity, and temperature. C. margaritaceum were also negatively affected by increasing concentrations of nitrite and nitrate. Considering that we made only one sampling in each environment, the richness was high compared to the mean diversity of lakes in the São Paulo State. The Diogo Lake, located in an ecological reserve, was the richest one, confirming the need of more research on the biodiversity of more preserved environments.
\end{abstract}

Keywords: ciliates, amoebae, plankton, environmental variables, freshwater.

BAGATINI, I.L., SPÍNOLA, A.L.G., PERES, B.M., MANSANO, A.S., RODRIGUES, M.A.A., BATALHA, M.A., LUCCA, J.V., GODINHO, M.J.L., TUNDISI, T.M. \& SELEGHIM, M.H.R. Protozooplâncton e suas relações com as condições ambientais em 13 corpos d'água da bacia do Rio Mogi-Guaçu - SP, Brasil. Biota Neotrop. 13(4): http://www.biotaneotropica.org.br/v13n4/pt/abstract?article+bn02913042013

Resumo: O protozooplâncton é um componente importante da rede trófica microbiana de ambientes aquáticos e sua composição, densidade e distribuição refletem os aspectos físicos, químicos e bióticos do ambiente. Considerando a escassa literatura sobre protozoários de água doce no Brasil e sobre sua ecologia em ambientes subtropicais, inventariamos os táxons de ciliados e amebas em 13 corpos d'água do Estado de São Paulo e analisamos a variação na abundância dos gêneros/espécies de maior incidência em relação às variáveis ambientais. Coletamos duas amostras por ambiente, fixando-as com cloreto de mercúrio e corando-as com azul de bromofenol para posterior quantificação e identificação em microscópio ótico. Identificamos 74 gêneros de ciliados e amebas, e os Ciliophora dominaram na maioria dos ambientes. A subclasse Stichotrichia ocorreu em todos os ambientes, predominando em cinco deles, especialmente pela ocorrência o gênero Halteria. A Análise de Correspondência Canônica mostrou que as concentrações de nitrito e nitrato são as principais variáveis que explicam a distribuição dos gêneros Limnostrombidium, Urotricha e Vorticella. O aumento na concentração de oxigênio dissolvido, condutividade, temperatura e concentração de fosfato particulado afetou positivamente a densidade dos gêneros Halteria e Coleps e da espécie Cinetochilum margaritaceum, que foi ainda influenciada negativamente pelo aumento nas concentrações de nitrito e nitrato. Considerando-se que foi realizada apenas uma coleta, a riqueza de espécies foi alta quando comparada à média de taxa encontrada para corpos d'água do Estado de São Paulo. O ambiente mais rico, Lagoa do Diogo, localiza-se em uma estação ecológica, confirmando a necessidade de mais pesquisas sobre a diversidade em ambientes menos impactados.

Palavras-chave: ciliados, amebas, plâncton, variáveis ambientais, água doce. 


\section{Introduction}

Protozoans can control microbial populations and also serve as food items for organisms of higher trophic levels, in addition, they act as important remineralizers and nutrient recyclers in aquatic environments (e.g. Beaver \& Crisman 1989a). Despite their cosmopolitan distribution, they are not evenly distributed, but live in microhabitats that reflect physical, chemical, and biotic environmental aspects (Lee et al. 1985). They can be excellent biological indicators, especially due to their small size, short generation times, stress sensibility, ease of sampling, and occurrence in many types of environments (Cairns Junior et al. 1993).

Despite their ecological importance and the possibility of using the species as important tools to evaluate the degree of environmental impact caused by human activity, the protozoans have not been studied enough and the data about their diversity and distributions are scarce, especially in Asia and South America (Lévêque et al. 2005).

Studies of aquatic systems are focused on larger organisms and the number of species in Brazilian continental aquatic communities is still imprecise and difficult to estimate. Among the difficulties we can highlight the great number of hydrographic basins never surveyed; insufficient infrastructure for samplings and number of researchers, the dispersion of information that are often difficult to access, and the need for taxonomic revision for many groups (Agostinho et al. 2005).

In Brazil, studies focusing on protists started around 1910 and since the 1980s have increased (Godinho \& Regali-Seleghim 1999). In São Paulo State, 75 freshwater environments have been analyzed until 2011 and 471 different protozoan taxa, distributed in 218 genera and 304 species, were recorded (Regali-Seleghim et al. 2011).

Since it is important to monitor the biodiversity to quantify human impacts in freshwater environments, aiming to improve their conservation (Lévêque et al. 2005), and considering the scarce data on freshwater protozoans from Brazil, we characterized the ciliate and sarcodine communities occurring in 13 water bodies of São Paulo State, which had not been studied previously, and analyzed the fluctuations of the most important genera in relation to the environmental variables.

\section{Material and Methods}

\section{Studied sites}

Two samples (replicates) were collected from each of the 13 shallow freshwater environments ( $3 \mathrm{~m}$ of maximum depth) located at the Mogi-Guaçu Water Resources Management Unit (UGRHI) from December 15th to 20th in 1999 (Table 1).
The Mogi-Guaçu UGRHI (Figure 1) has a catchment area of $14,653 \mathrm{~km}^{2}$ composed by urban, industrial and rural regions. These last ones are used for livestock, poultry farming and agricultural activities that are predominantly cultures of sugar cane, coffee, citrus, corn and cotton. The main agro-industrial sectors are the sugar and alcohol, vegetable oils, beverages and cellulose and paper industries (COMPANHIA... 2001).

The region also has an important conservation area called Jataí Ecological Station, located in the municipality of Luis Antônio, where one of the water bodies was sampled, the Diogo Lake (DL). Among the other environments, the Paço Municipal Lake (PML), the Praça Basílio Ceschin Pond (PBC), the Urban Lake of Santa Cruz da Conceição (UL), the Prainha Pond (PP), the Elektro Reservoir (ER), the Araras Municipal Lake (LMA) and the David Reservoir (DR) are urban aquatic environments. The other sites are located within rural properties: Barro Preto Pond (BPP), Cabras Pond (CP), Ivo Carotini Lake (ICL), the Fazenda Aurora Reservoir (FAR) and São Geraldo Reservoir (SGR). Table 1 shows the cities locations and dates of sampling for each environment.

\section{Collection and fixation of samples}

Water samples were collected with a bucket from de edge of the water bodies. For protozoan analysis, we immediately fixed replicates of $200 \mathrm{ml}$ aliquots with a saturated solution of mercuric chloride and stained with bromophenol blue (Pace \& Orcutt 1981). The samples were concentrated by sedimentation and the supernatant was rejected. Protozoans were counted and identified in triplicates in $1 \mathrm{~mL}$ Sedgwick-Rafter chambers under an optic microscope (100 to $200 \mathrm{x}$ magnification).

For species identification, we used the following references: Bick (1972), Corliss (1979), Curds (1969), Dragesco \& Dragesco-Kernéis (1986), Edmondson (1959), Foissner et al. (1991, 1992, 1994, 1995, 1999), Foissner \& Berger (1996), Kahl (1930-35), Krainer (1991), Kudo (1977), Lee et al. (1985), Page (1976) and Pennak (1953). The protozoans were separated in groups according to the classification proposed by Lynn (2008) for ciliates and Adl et al. (2005) for Amoebozoa, Centrohelida and Rhizaria.

\section{Physical and chemical variables}

The $\mathrm{pH}$, dissolved oxygen $\left(\mathrm{mg} \mathrm{O}_{2} \mathrm{~L}^{-1}\right)$, temperature $\left({ }^{\circ} \mathrm{C}\right)$, and electrical conductivity $\left(\mu \mathrm{S} \mathrm{cm} \mathrm{cm}^{-1}\right)$ of water samples were measured with a multiparameter probe (Horiba U-10). The dissolved organic phosphate (DOP) concentration was obtained by the difference between dissolved inorganic phosphate concentration (DIP) and total dissolved phosphate concentration quantified according to

Table 1. Location and sampling date for each studied water body.

\begin{tabular}{|c|c|c|c|c|}
\hline Site & City & Coordinates & Feature & Sampling date \\
\hline Paço Municipal Lake (PML) & Jaboticabal & $21^{\circ} 15^{\prime} 23.19^{\prime \prime} \mathrm{S}$ and $48^{\circ} 18^{\prime} 27.40^{\prime \prime} \mathrm{W}$ & Urban & $18 / 12 / 1999$ \\
\hline Ivo Carotini Lake (ICL) & Águas de Lindóia & $22^{\circ} 28^{\prime} 32.36^{\prime \prime} \mathrm{S}$ and $46^{\circ} 37^{\prime} 32.65^{\prime \prime} \mathrm{W}$ & Rural & 21/12/1999 \\
\hline Araras Municipal Lake (AML) & Araras & $22^{\circ} 21^{\prime} 39.43^{\prime \prime} \mathrm{S}$ and $47^{\circ} 23^{\prime} 1.24^{\prime \prime} \mathrm{W}$ & Urban & $21 / 12 / 1999$ \\
\hline Urban Lake (UL) & Santa Cruz da Conceição & $22^{\circ} 8^{\prime} 3.00^{\prime \prime} \mathrm{S}$ and $47^{\circ} 27^{\prime} 35.63^{\prime \prime} \mathrm{W}$ & Urban & $15 / 12 / 1999$ \\
\hline Cabras Pond (CP) & Guatapará & $21^{\circ} 29^{\prime} 52.35^{\prime \prime} \mathrm{S}$ and $48^{\circ} 2^{\prime} 10.44^{\prime \prime} \mathrm{W}$ & Rural & $16 / 12 / 1999$ \\
\hline Praça Basílio Ceschin Pond (PBC) & Águas da Prata & $21^{\circ} 56^{\prime} 3.60^{\prime \prime} \mathrm{S}$ and $46^{\circ} 42^{\prime} 56.82^{\prime \prime} \mathrm{W}$ & Urban & 20/12/1999 \\
\hline Prainha Pond (PP) & Pitangueiras & $21^{\circ} 0^{\prime} 30.12^{\prime \prime} \mathrm{S}$ and $48^{\circ} 13^{\prime} 9.96^{\prime \prime} \mathrm{W}$ & Urban & $18 / 12 / 1999$ \\
\hline Barro Preto Pond (BPP) & Guatapará & $21^{\circ} 29^{\prime} 52.35^{\prime \prime} \mathrm{S}$ and $48^{\circ} 2^{\prime} 10.44^{\prime \prime} \mathrm{W}$ & Rural & $16 / 12 / 1999$ \\
\hline Diogo Lake (DL) & Luiz Antônio & $21^{\circ} 37^{\prime} 25.57^{\prime \prime} \mathrm{S}$ and $47^{\circ} 48^{\prime} 36.75^{\prime \prime} \mathrm{W}$ & Ecological Station & $16 / 12 / 1999$ \\
\hline Elektro Reservoir (ER) & Pirassununga & $21^{\circ} 55^{\prime} 34.94^{\prime \prime} \mathrm{S}$ and $47^{\circ} 22^{\prime} 3.19^{\prime \prime} \mathrm{W}$ & Urban & $15 / 12 / 1999$ \\
\hline Fazenda Aurora Reservoir (FAR) & Santa Cruz das Palmeiras & $21^{\circ} 48^{\prime} 46.36^{\prime \prime} \mathrm{S}$ and $47^{\circ} 12^{\prime} 37.62^{\prime \prime} \mathrm{W}$ & Rural & $15 / 12 / 1999$ \\
\hline David Reservoir (DR) & Santa Cruz das Palmeiras & $21^{\circ} 49^{\prime} 35.94^{\prime \prime} \mathrm{S}$ and $47^{\circ} 14^{\prime} 44.19^{\prime \prime} \mathrm{W}$ & Urban & $15 / 12 / 1999$ \\
\hline São Geraldo Reservoir (SGR) & Sertãozinho & $21^{\circ} 77^{\prime} 37.70^{\prime \prime} \mathrm{S}$ and $48^{\circ} 2^{\prime} 42.67^{\prime \prime} \mathrm{W}$ & Rural & $18 / 12 / 1999$ \\
\hline
\end{tabular}


Bagatini, I.L. et al.

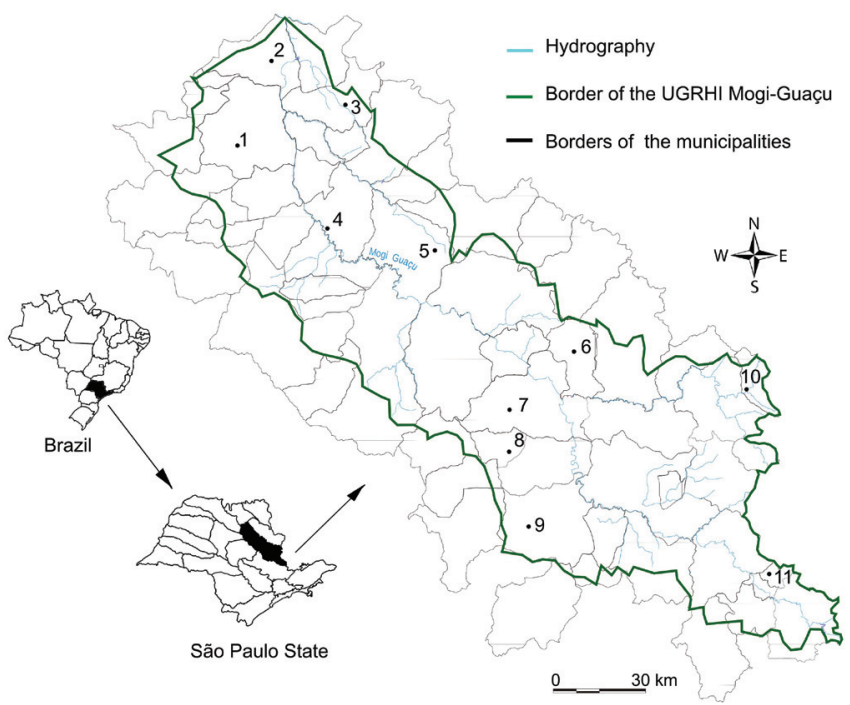

Figure 1. The Mogi-Guaçu Water Resources Management Unit (UGRHI Mogi-Guaçu). The numbers represent the municipalities sampled: 1 Jaboticabal, 2 Pitangueiras, 3 Sertãozinho, 4 Guatapará, 5 Luís Antônio, 6 Santa Cruz das Palmeiras, 7 Pirassununga, 8 Santa Cruz da Conceição, 9 Araras, 10 Águas da Prata, 11 Águas de Lindóia. (http://www.sigrh.sp.gov. br/sigrh/basecon/r0estadual/sintese/images/ugrhi09.pdf - modified).

Strickland \& Parsons (1960). We quantified the total nitrogen and total phosphorus according to Valderrama (1981); nitrate $\left(\mathrm{N}-\mathrm{NO}_{3}\right)$ according to Mackereth et al. (1978); nitrite $\left(\mathrm{N}-\mathrm{NO}_{2}\right)$ according to Bendchreider \& Robinson (1952, cited in Golterman et al. 1978) and ammonium (N-NH$)$ according to Koroleff (1976). The particulate phosphate (Part.P) was calculated by the difference between total phosphorus and total dissolved phosphate.

\section{Statistical analysis}

All statistical tests were conducted in the R computing environment (R Development Core Team 2009), with statistical significance set at $p<0.05$. The Spearman rank correlation coefficient ( $\rho$ ) was used to test linear correlations. For multivariate analyses, the environmental variables were standardized by $\mathrm{Z}$-score transformation and the $\mathrm{pH}$ was withdrawn from the analysis due to its high linear correlation with Dissolved Oxygen $(\rho=0.84$, p-value $<0.001)$. An ordination diagram resulting from the Principal Component Analysis (PCA) was used to summarize the environmental variables differences among the studied sites. The optimal model for the Canonical Correspondence Analysis (CCA) was selected by the Akaike Information Criterion (AIC). In the CCA diagram, only the genera with higher frequency (occurring at least in six environments) were used.

\section{Results}

\section{Physical and chemical analyses: differences between the studied sites}

The diagram of the PCA (Figure 2) with the abiotic variables summarizes the relationships of these variables in the different studied sites, which are grouped according to the environment type: rural, urban, or conservation unit. The first axis of the PCA explained $31.4 \%$ of the variation and is mainly associated with dissolved oxygen, total particulate phosphorus, temperature, and conductivity.

The second axis of the PCA (Figure 2), which explains $25.5 \%$ of the environmental variation among the samplings (sites) is mainly associated with dissolved phosphate (organic and inorganic), nitrite

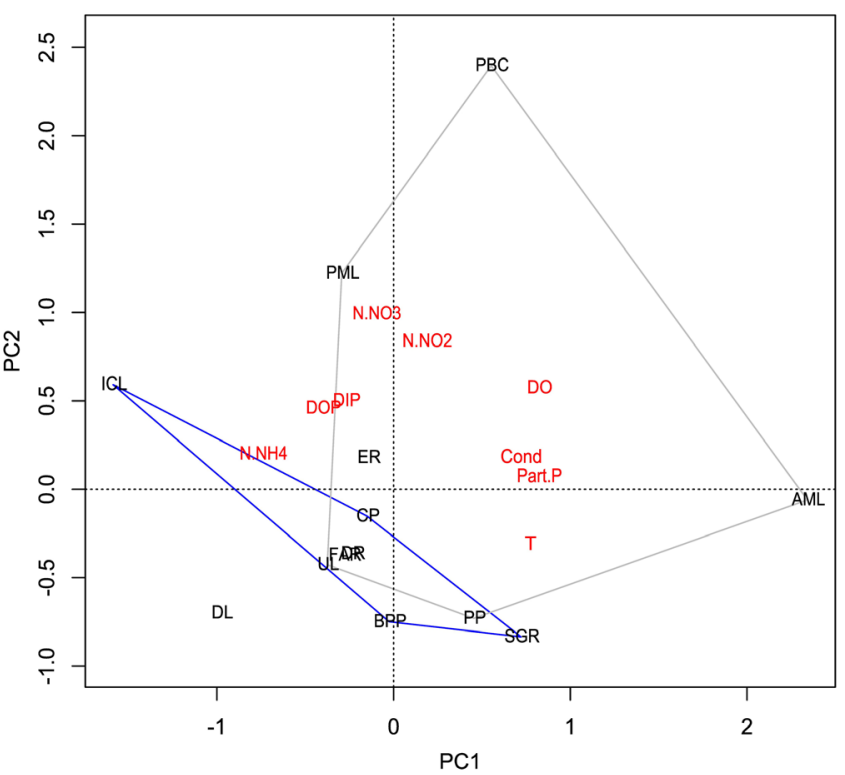

Figure 2. Diagram of Principal Component Analysis (PCA) applied to environmental variables. Proportion explained by axis: $31.5 \%$ (PC1) and $25.5 \%$ (PC2). Sites are connected by type: urban (gray line), rural (blue line) and ecological station (just site DL).

and nitrate. Among the samples that had the lowest scores for this axis are the ones from the DL $(-0.70)$ and the BPP $(-0.75)$, in which we found the greatest richness of morphotypes: 73 and 71 , respectively. These environments, unlike the other two that had the lowest scores for axis 2, the SGR $(-0.83)$ and the PP $(-0.73)$, also had negative scores for axis 1 .

\section{Protozooplankton community structure}

We identified 69 species belonging to 50 genera, and other 24 genera were not identified to the species level, totalizing 74 genera in the 13 environments (Appendix 1). The protozoa were separated into four major groups: Ciliophora, Amoebozoa, Rhizaria and Centrohelida (Heliozoa). Amoebozoa and Rhizaria make up the artificial group of amoebas.

When the identification at lower taxonomical level was not possible, we separated the specimens by morphotypes. The morphotype was used as richness unit, however, similar morphotypes from different environments were not compared. Thus, the sum of the richness of the 13 environments should not be considered as an estimate of total richness.

Once the material was fixed, the identification of some naked amoebae was limited, since many taxonomic characteristics of this protozoan group are related to their locomotion (Page 1976). This rendered difficult the separation between the major groups Rhizaria and Amoebozoa, therefore these morphotypes were assigned as "naked amoebae" in figures and tables.

Among the 13 environments, the Diogo Lake was the richest (73 taxa), whereas the Elektro reservoir presented the lowest richness (3 taxa) (Table 2). Although not significantly different, the mean richness of rural environments (excluding the ecological station) was higher (27.4 morphotypes) than mean richness of urban environments (15 morphotypes).

In number of taxa, the Ciliophora dominated most of the environments, except São Geraldo Reservoir, where the numbers of taxa of amoebae and Ciliophora were the same (Table 2). In the plankton of Praça Basílio Ceschin Pond (PBC), Araras Municipal Lake (AML) and Elektro Reservoir (ER) there were no amoebae. 
Protozooplankton in the Mogi-Guaçu basin, Brazil

Table 2. Protozoan richness (morphotypes) and density (cell. $\mathrm{mL}^{-1}$ ) for the studied environments: BPP (Barro Preto Pond), CP (Cabras Pond), DL (Diogo Lake), ICL (Ivo Carotini Lake), AML (Araras Municipal Lake), PP (Prainha Pond), PML (Paço Municipal Lake), UL (Urban Lake), PBC (Praça Basílio Ceschin Pond), DR (David Reservoir), ER (Elektro Reservoir), FAR (Fazenda Aurora Reservoir) and SGR (São Geraldo Resevoir). X is the mean value for the environments.

\begin{tabular}{|c|c|c|c|c|c|c|c|c|}
\hline & \multicolumn{4}{|c|}{ Richness } & \multicolumn{4}{|c|}{ Density (ind.mL ${ }^{-1}$ ) } \\
\hline & Total & Cil. & Ameboid & Heliozoa & Total & Cil. & Ameboid & Heliozoa \\
\hline LBP & 71 & 57 & 14 & 0 & 16.02 & 15.17 & 0.85 & 0 \\
\hline $\mathbf{C P}$ & 28 & 24 & 2 & 2 & 12.57 & 11.57 & 0.95 & 0.05 \\
\hline DL & 73 & 66 & 7 & 0 & 3.33 & 3.12 & 0.21 & 0 \\
\hline ICL & 18 & 17 & 1 & 0 & 18.80 & 16.99 & 1.81 & 0 \\
\hline AML & 6 & 6 & 0 & 0 & 51.91 & 51.91 & 0 & 0 \\
\hline PP & 28 & 26 & 2 & 0 & 10.48 & 6.18 & 4.30 & 0 \\
\hline PML & 22 & 14 & 8 & 0 & 9.91 & 4.16 & 5.75 & 0 \\
\hline $\mathbf{U L}$ & 10 & 9 & 1 & 0 & 30.68 & 2.03 & 28.65 & 0 \\
\hline PBC & 12 & 12 & 0 & 0 & 10.20 & 10.20 & 0 & 0 \\
\hline DR & 24 & 23 & 1 & 0 & 5.44 & 5.42 & 0.02 & 0 \\
\hline ER & 3 & 3 & 0 & 0 & 0.60 & 0.60 & 0 & 0 \\
\hline FAR & 4 & 3 & 1 & 0 & 84.93 & 61.10 & 23.83 & 0 \\
\hline SGR & 16 & 8 & 8 & 0 & 5.29 & 5.14 & 0.15 & 0 \\
\hline $\mathbf{X}$ & 24.23 & 20.62 & 3.46 & 0.15 & 20.01 & 14.89 & 5.12 & 0.00 \\
\hline
\end{tabular}

Ciliophora was also more abundant in most environments, except for the Prainha Pond (PP), where its density was similar to amoebae, and for the Paço Municipal (PML) and Urban (UL) lakes, where amoebae was more abundant. The total density of protozoans varied from 596 ind. $\mathrm{L}^{-1}$, in the Elektro Reservoir (ER), to $84.93 \times 10^{3}$ ind. $\mathrm{L}^{-1}$, in the Fazenda Aurora Reservoir (FAR) (Table 2).

Except for the Diogo Lake, the sum of the three dominant taxa corresponded to more than $50 \%$ of the total protozooplankton in the environments (Table 3). The genus Halteria occurred among the dominant species in 11 environments. Amoebae species dominated numerically in the Urban Lake (Pseudodifflugia sp), in the Paço Municipal Lake (genus Mayorella) and in the Prainha Pond.

Among the groups found, 18 in total, only Stichotrichia was present in all 13 environments (Table 4) and was predominant in five of them (Figure 3), especially by the occurrence of Halteria. The Stichotrichia, along with subclasses Choreotrichia and Oligotrichia, belongs to the class Spirotrichea (Lynn 2008). These two subclasses and Prorodontida (Class Prostomatea in the current classification and Prostomatida according to Foissner et al. (1999)) occurred in 10 environments, whereas Peritrichia occurred in 12.

Despite the wide distribution of Peritrichia, it occurred among the three most important groups in the plankton of only four environments (Figure 3), and made up from 1.1\% (Cabras Pond) to 90\%, (Elektro Reservoir) of the protozooplankton community.

\section{Influence of environmental variables on protozooplankton}

The most abundant genera/species that occurred in more than six environments were also analyzed in relation to the nine environmental variables through CCA. The best CCA model, according to the Akaike Information Criterion, was the complete model (Figure 4) and was significant $(\mathrm{p}=0.037)$. The proportion of the variation in the distribution of the genus/species explained by the axis 1 of the CCA was $39.8 \%$, whereas the axis 2 explained $25.5 \%$. The speciesenvironment correlation was high for the first two axes of CCA: 0,993 and 0,989 .

The CCA showed that the genera Pseudodifflugia and Mesodinium were positively influenced by the orthophosphate concentration and negatively affected by conductivity, particulate phosphate, dissolved oxygen, and temperature. The forms of nitrogen did not affect the distribution of these genera.
The concentrations of nitrite and nitrate are the main variables that explain the distribution of Enchelys, Rimostrombidium, Paradileptus, and, especially, Limnostrombidium, Urotricha, and Vorticella, which occur also in environments with higher concentrations of orthophosphate.

The increase in the concentration of dissolved oxygen, particulate phosphate, conductivity, and temperature affects positively the density of the genera Coleps and Halteria and the species Cinetochilum margaritaceum (Ehrenberg, 1831) Perty, 1849. This species is negatively affected by increase on nitrite and nitrate concentrations. Since DO is strongly related with $\mathrm{pH}$, it was assumed that these variables have similar influences on the distribution of the protozoan genus/species in this work.

\section{Discussion}

In our work, it was not possible to make a reliable characterization of the environments since they were sampled only once, but it was possible to show that there were differences among the samples and that it likely reflects some differences in the catchment area and in the human activities around the environments, as there were a separation among rural and urban environments in the PCA, and it also influenced protozoan community.

Among the samples with lowest scores for the axis 2 (related with dissolved phosphate, nitrite and nitrate) of the PCA are the ones from DL and BPP that presented the greatest richness of morphotypes. Our results showed higher richness in samples (environments) with lower concentration of dissolved phosphate and nitrogen forms, what differs from the results obtained by Buosi et al. (2011) that showed increasing richness of ciliate community in response to nutrients amendment in Brazilian aquatic environment. Beaver \& Crisman (1989b), also found, for 30 Florida (subtropical) lakes, that ciliate species richness is positively related to lake productivity, and the richest lake (hypereutrophic) had 24.5 species. Our contrasting results may be due to the unique sampling for each environment or to other variables than phosphate and nitrogen influencing the productivity of the environments, since the BPP is a rural environment and DL lies within a conservation area and probably suffers less anthropic influence.

The richness of morphotypes in the analyzed environments in UGRHI-Mogi-Guaçu was higher than the mean found in other water 


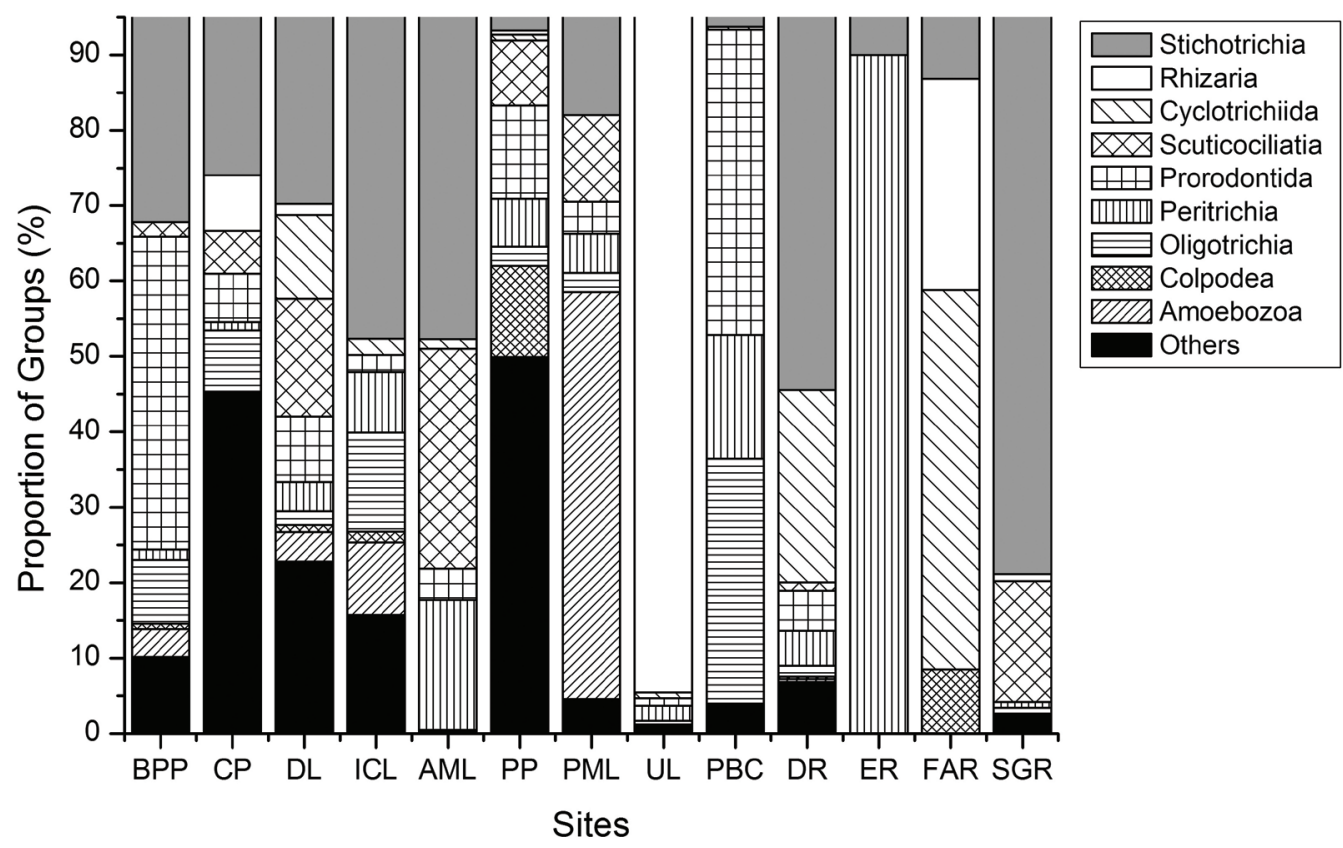

Figure 3. Major groups and their relative abundances in the 13 studied environments. BPP (Barro Preto Pond), CP (Cabras Pond), DL (Diogo Lake), ICL (Ivo Carotini Lake), AML (Araras Municipal Lake), PP (Prainha Pond), PML (Paço Municipal Lake), UL (Urban Lake), PBC (Praça Basílio Ceschin Pond), DR (David Reservoir), ER (Elektro Reservoir), FAR (Fazenda Aurora Reservoir) and SGR (São Geraldo Reservoir).

Table 3. Dominant taxa in the 13 studied environments and their relative abundances. $\Sigma=$ sum of relative abundances.

\begin{tabular}{|c|c|c|c|c|}
\hline & \multicolumn{4}{|c|}{ Dominant taxa } \\
\hline & $\Sigma$ & 1 & 2 & 3 \\
\hline Ivo Carotini Lake & $70.4 \%$ & Halteria cirrifera $(47.6 \%)$ & Limnotrombidium sp (13.1\%) & Arcella sp (9.6\%) \\
\hline Praça Basílio Ceschin Pond & $72.6 \%$ & Limnostrombidium sp (32.5\%) & Urotricha globosa $(20.6 \%)$ & U. cf. agilis $(19.5 \%)$ \\
\hline Barro Preto Lake & $71.9 \%$ & Urotricha cf. agilis (34.6\%) & Halteria grandinella $(28.8 \%)$ & Limnostrombidium viride $(8.5 \%)$ \\
\hline Cabras Pond & $51.6 \%$ & Halteria cf grandinella $(25.5 \%)$ & Tintinnidium cf. semiciliatum $(17.3 \%)$ & Rimostrombidium humile (8.8\%) \\
\hline Diogo Lake & $45.6 \%$ & Halteria grandinella $(24.3 \%)$ & Mesodinium pulex (11.1\%) & Cinetochilum margaritaceum $(10.2 \%)$ \\
\hline Prainha Pond & $57.2 \%$ & "Naked amoebae" (40.5\%) & Urotricha $\mathrm{sp}(8.7 \%)$ & C. margaritaceum $(8 \%)$ \\
\hline Paço Municipal Lake & $71.7 \%$ & Mayorella cf. limacis (40.7\%) & Halteria grandinella $(17.8 \%)$ & Mayorella bicornifrons (13.3\%) \\
\hline David Reservoir & $77 \%$ & Stichotricha secunda (42.8\%) & Askenasia volvox $(24.1 \%)$ & Halteria sp. (10.1\%) \\
\hline Elektro Reservoir & $100 \%$ & Vorticella aquadulcis (85\%) & Halteria grandinella $(10 \%)$ & Epistylis sp. (5\%) \\
\hline São Geraldo Reservoir & $95.3 \%$ & Halteria grandinella $(78.3 \%)$ & C. margaritaceum (16.1\%) & Pseudodifflugia sp (0.9\%) \\
\hline Urban Lake & $96.2 \%$ & Pseudodifflugia sp. (93.4\%) & Campanella sp. (1.6\%) & Halteria sp. (1.2\%) \\
\hline Araras Municipal Lake & $94 \%$ & Halteria sp. $(47.7 \%)$ & C. margaritaceum $(29.2 \%)$ & Vorticella mayeri $(17.2 \%)$ \\
\hline Fazenda Aurora Reservoir & $91.5 \%$ & Mesodinium sp. $(50.3 \%)$ & Pseudodifflugia sp. (28.1\%) & Halteria sp. (13.1\%) \\
\hline
\end{tabular}

Table 4. Protozoan groups found and the number of environments (N.E.) in which they occurred.

\begin{tabular}{cccccc}
\hline Group & N.E. & Group & N.E. & Group & N.E. \\
\hline Stichotrichia & 13 & Scuticociliatia & 8 & Hymenostomatia & 2 \\
Peritrichia & 12 & Peniculia & 7 & Pleurostomatida & Armophorea \\
Prorodontida & 10 & Colpodea & 6 & Amoebozoa & 7 \\
Choreotrichia & 10 & Cytphoria & 3 & Rhizaria & 6 \\
Oligotrichia & 10 & Heterotrichia & 3 & Centrohelida & 1 \\
Cyclotrichiida & 8 & Karyorelictea & 3 & "Naked amoebae" & 5 \\
Haptorida & 8 & Suctoria & 3 &
\end{tabular}

bodies from São Paulo State. According to Regali-Seleghim et al. (2011), the richness of taxa was between 17 and 20, on water bodies that have been analyzed just once in Biota/FAPESP. Regali-Seleghim (2001) found a maximum of 58 taxa in one sampling in a shallow water body, the Monjolinho lake in São Carlos, after a study of 1 year and six months with monthly sampling. Gomes \& Godinho (2003) have related 28 taxa of Sarcodina and Ciliophora to the eutrophic lake Monte Alegre, Ribeirão Preto - SP, during a period of one year.

Considering the sampling effort for each environment and the relative high richness found in some of them, we highlight the necessity of this kind of study in poorly explored environments. Agostinho et al. (2005) reports that preservation of fauna and flora 


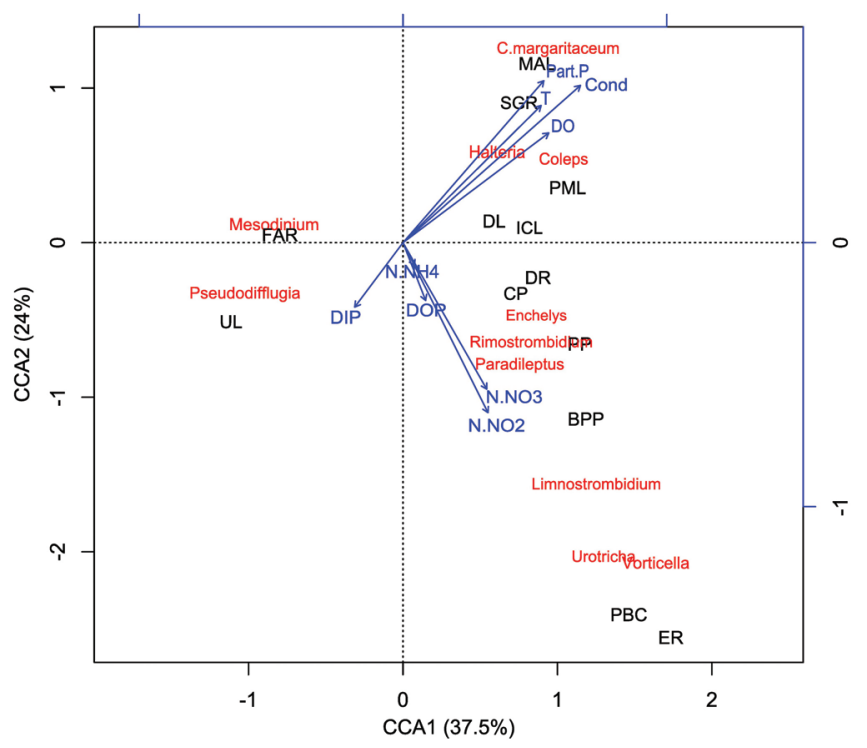

Figure 4. Canonical Correspondence Analysis (CCA) ordination diagram showing the relationships between more frequent (i.e. present in six or more sites) protozoan genera and environmental variables. The unique species of the genus Cinetochilum was $C$. margaritaceum.

has been the main reason to the establishment of the major protected areas in Brazil on the last decades. Several environments from these areas include water bodies and wetlands, but their fauna and flora, aquatic and terrestrial, have been little studied or surveyed. Protected areas in which aquatic organisms have been intensely inventoried show the importance of these efforts for biodiversity conservation (Agostinho et al. 2005).

Despite the high richness found, comparatively to other studies, all the environments presented relatively low densities (Table 2). Beaver \& Crisman (1989a) found that the number of ciliate in oligotrophic lakes is below 10 ind. $\mathrm{mL}^{-1}$, whereas more productive lakes exhibit greater abundance. In Brazilian reservoirs, however, lower ciliate cell concentrations are recorded in eutrophic environments: in Iraí reservoir (Paraná) ciliate density ranged from 7.2 to 47.1 ind. $\mathrm{mL}^{-1}$ (Velho et al., 2005), in São Paulo State, protozoan densities ranged from 3.60 to 389 ind. $\mathrm{mL}^{-1}$ in Monte Alegre Lake (Gomes \& Godinho 2003) and in Monjolinho lake, ciliate densities ranged from 6.21 to 98.07 ind. $\mathrm{mL}^{-1}$, and amoebae from 0.54 to 22.46 ind. $\mathrm{mL}^{-1}$ (RegaliSeleghim 2001).

Concerning the dominant ciliates in this work, several are frequently reported in Brazilian aquatic environments, such as Halteria grandinella (Müller, 1973) Dujardin, 1841, Cinetochilum margaritaceum Limnostrombidium sp., Mesodinium sp., Urotricha spp. and Vorticella spp. (e.g. Barbieri \& Godinho-Orlandi 1989, Buosi et al. 2011, Dias et al. 2008, Gomes \& Godinho 2003, Mansano et al. 2013, Pauleto et al. 2009, Regali-Seleghim et al. 2011), and have widespread geographic distribution in Brazil (Foissner et al. 1999, Šimek et al. 2000).

The abundance of amoebae was lower than ciliates considering most environments. Despite some authors claim that amoebas are poorly known in freshwater plankton (e.g. Laybourn-Parry 1992), studies have shown the importance of testate amoebae in plankton of some Brazilian environments (Alves et al. 2010, Bini et al. 2003, Costa et al. 2011, Lansac-Tôha et al. 2007, Velho et al. 2003). Arndt (1993), in a review about planktonic groups from freshwater, claims that amoebae have been underestimated on limnological studies because of methodological problems, even though rarely they could be as abundant as, or even more abundant than ciliates.

The amoeba of the genus Mayorella was predominant in the PML. The predominance of amoebas could be related to eutrophication, since Mayorella has been specially associated to cyanobacteria grazing in freshwater and saltwater environments (Cook et al. 1974, Laybourn-Parry et al. 1987). This environment presented high score to PCA axis 2 (Figure 2), related to dissolved phosphate and nitrate, which are the main nutrients associated to eutrophication of aquatic environments (Kratzer \& Brezonik 1981, Toledo Junior et al. 1983).

Among the main protozoa, the genus Halteria is noteworthy, especially because of the species $H$. grandinella. Researches about the protozoa composition in Brazilian water bodies - Lobo Reservoir (São Carlos, SP), Rio Grande Reservoir (São Paulo, SP), Ilha Solteira Reservoir (Ilha Solteira, SP), reservoirs in the basin of Piranhas-Assu River (Rio Grande do Norte state), Lake Monte Alegre (Ribeirão Preto, SP) and Monjolinho Reservoir (São Carlos, SP) - found that $H$. grandinella was among the most frequent and abundant species in these environments (Araújo \& Costa 2007, Barbieri \& GodinhoOrlandi 1989, Gomes \& Godinho 2003, Mansano et al. 2013, RegaliSeleghim 1992, 2001).

The Halteria spp. dominance could be due to characteristics such as wide diet and effective escape from predation. According Jürgens \& Šimek (2000), Halteria spp feeds on organisms belonging to several trophic levels (bacteria, nanoprotists, algae, debris), what can be a selective advantage compared to specialized ciliates, resulting in a wide occurrence and, in most cases, dominance of Halteria spp. in freshwater plankton. In addition, its ability to jump could improve their chances of survival in the environment. According to Gilbert (1994) and Jack \& Gilbert (1997), the jumper habit is an effective strategy to escape from predatory by cladocerans and rotifers.

The Halteria genus was responsible for the higher frequency of Stichotrichia in the environments. This subclass, along to Choreotrichia and Oligotrichia, represented by Rimostrombidium and Limnostrombidium, belongs to Oligotrichida group, according to Foissner et al. (1999). Oligotrichida are common in the communities of oligotrophic to hypereutrophic sub-tropical lakes throughout the annual cycle (Beaver \& Crisman 1990, LaybournParry 1992). In studies conducted in subtropical water bodies by Regali-Seleghim et al. (unpublished data) in UGRHI Pardo, the taxonomic group with greater abundance was Oligotrichida, followed by Prostomatida, Hymenostomata (subdivided into Hymenostomatia, Peniculia and Scuticociliatia on the current classification), and Gymnostomatea (Haptorida on the current classification). Beaver \& Crisman $(1982,1990)$ found predominance of Oligotrichida, Scuticocilatida and Haptorida in sub-tropical Florida lakes and the lacustrine protozooplankton have a significant haptorid (Gymnostomatea), peritrich (Laybourn-Parry 1992), and scuticociliate (within Hymenostomata) component (Beaver \& Crisman 1989a).

Whereas a major part of researches about protozoa ecology uses the separation into groups proposed by Foissner et al. (1991, 1992, 1994, 1995), which brings together the genera Halteria, Limnostrombidium, and Rimostrombidium into Oligotrichida, our CCA showed that these genera, specially Halteria, respond to environmental variables on different ways. Although it would be necessary a greater number of sampling points to more robust interpretation of genera distribution, considering the 13 points and their abiotic differences, it was possible to make same inferences about the distribution of main genera in relation to the environmental variables, and the CCA was significant. Increasing total sampling points would improve interpretation of protozoan distribution, but 
fewer samples do not invalidate statistical analyses, only restricts the interpretation and extrapolation of data.

In our work, Limnostrombidium, Rimostrombidium, Urotricha and Vorticella were more affected by inorganic nitrogen variation. Buosi et al. (2011) found a slight increase in Limnostrombidium sp. density in treatments enriched with phosphorus and nitrogen. Furthermore, nitrite and nitrate, which are easily assimilated by phytoplankton, may indirectly affect the distribution of Limnostrombidium spp, since many species of this genus shows mixotrophy (Laybourn-Parry et al. 1990), Urotricha spp, which is a herbivorous genus (Weisse \& Frahm 2001), and Vorticella spp, which occurs specially in eutrophic environments and many are algae and cyanobacteria epibionts (Bick 1972, Laybourn-Parry et al. 1990).

The genera Halteria and Coleps, and C. margaritaceum were positively influenced by the concentration of dissolved oxygen, conductivity, temperature and particulate phosphate, and poorly or negatively related to nitrogen forms. $H$. grandinella and $C$. margaritaceum are more abundant in environments poor in nitrogen compounds, but with higher amounts of organic matter (Bick 1972). Since these ciliates were influenced by DO, they might also have been influenced by $\mathrm{pH}$, due to the strong correlation between these variables. This correlation could be indicative of higher photosynthetic rates in the environments, since the release of oxygen by phytoplankton is associated with the consumption of carbon dioxide during photosynthesis, what may increase the $\mathrm{pH}$ of the environment. Mansano et al. (2013) reported positive correlation among $H$. grandinella density and $\mathrm{DO}$, but no correlation with $\mathrm{pH}$.

Regarding to the $\mathrm{pH}, C$. margaritaceum was more abundant in more alkaline environments and Limnostrombidium and Rimostrombidium predominated in environments with lower $\mathrm{pH}$ values. These results corroborate those described by Mieczan (2007).

The genus Coleps and C. margaritaceum were found in similar environments. The species Coleps hirtus feeds on C. margaritaceum, avoids high concentrations of ammonium (Foissner et al. 1999) and has optimum growth at low concentrations of nitrite and nitrate (Bick 1972).

Besides the different responses of the most commons genera/ species to the environmental variables, this work showed that although all the environments studied belong to one basin, they were different in composition of species, reflecting differences in nutrient concentration of the water bodies and possibly in the land use, since we found lower mean richness in urban environments. Galbraith \& Burns (2010) suggest that differences in taxonomic structure of ciliate and phytoplankton communities might also be predicted by the land use and vegetation cover in the catchment. Our results corroborate the need of more research in more preserved environments.

\section{Acknowledgments}

We are thankful to Airton Soares for help in the field, to Fernando Racy for valuable discussions and to FAPESP (Fundação de Amparo à Pesquisa do Estado de São Paulo) for financial support of the BIOTA program (Process n 98/05091-2).

\section{References}

ADL, S.M., SIMPSON, A.G.B., FARMER, M.A., ANDERSEN, R.A., ANDERSON, O.R., BARTA, J.R., BOWSER, S.S., BRUGEROLLE, G., FENSOME, R.A., FREDERIC, S., JAMES, T.Y., KARPOV, S., KUGRENS, P., KRUG, J., LANE, C.E., LEWIS, L.A., LODGE, J., LYNN, D.H., MANN, D.G., MCCOURT, R.M., MENDOZA, L., MOESTRUP, Ø., MOZLEY-STANDRIDGE, S.E., NERAD, T.A., SHEARER, C.A., SMIRNOV, A.V., SPIEGEL, F.W. \& TAYLOR, M.F.J.R. 2005. The New Higher Level Classification of Eukaryotes with
Emphasis on the Taxonomy of Protists. J. Eukaryot. Microbiol. 52(5):399451. http://dx.doi.org/10.1111/j.1550-7408.2005.00053.x

AGOSTINHO, A.A., THOMAZ, S.M. \& GOMES, L.C. 2005. Conservação da biodiversidade em águas continentais do Brasil. Megadiversidade. 1(1):70-78.

ALVES, G.M., VELHO, L.F., SIMÕES, N.R. \& LANSAC-TÔHA, F.A. 2010. Biodiversity of testate amoebae (Arcellinida and Euglyphida) in different habitats of a lake in the Upper Paraná River floodplain. Eur. J. Protistol. 46:310-318. http://dx.doi.org/10.1016/j.ejop.2010.07.001

ARAÚJO, M.F.F. \& COSTA, I.A.S. 2007. Comunidades microbianas (bacterioplâncton e protozooplâncton) em reservatórios do semiárido brasileiro. Oecol. Bras. 11:422-432. http://dx.doi.org/10.4257/ oeco.2007.1103.11

ARNDT, H. 1993. A critical review of the importance of rhizopods (naked and testate amoebae) and actinopods (heliozoan) in lake plankton. Mar. Microb. Food Webs. 7(1):3-29.

BARBIERI, S.M. \& GODINHO-ORLANDI, M.J.L. 1989. Planktonic protozoa: in a typical reservoir: temporal variation in abundance and composition. Rev. Hydrobiol. Trop. 22(4):275-285.

BEAVER, J.R. \& CRISMAN, T.L. 1982. The trophic response of ciliated protozoans in freshwater lakes. Limnol. Oceanogr. 27:246-253. http:// dx.doi.org/10.4319/10.1982.27.2.0246

BEAVER, J.R. \& CRISMAN, T.L. 1989a. The role of ciliated protozoa in pelagic freshwater ecosystems. Microb. Ecol. 17:111-136. http://dx.doi. org/10.1007/BF02011847

BEAVER, J.R. \& CRISMAN, T.L. 1989b. Analysis of the community structure of planktonic ciliated protozoa relative to trophic state in Florida lakes. Hydrobiologia. 174:177-184. http://dx.doi.org/10.1007/BF00008155

BEAVER, J.R. \& CRISMAN, T.L. 1990. Seasonality of planktonic ciliated protozoa in 20 subtropical Florida lakes of varying trophic state. Hydrobiologia. 190:127-135. http://dx.doi.org/10.1007/BF00014103

BICK, H. 1972. Ciliated protozoa. An illustrated guide to the species as biological indicators in freshwater. World Health Organization, Geneva.

BINI, L.M., VELHO, L.F.M. \& LANSAC-TÔHA, F.A. 2003. The effect of connectivity on the relationship between local and regional species richness of testate amoebae (Protozoa, Rhizopoda) in floodplain lagoons of the Upper Paraná River, Brazil. Acta Oecol. 24(1):145-151. http:// dx.doi.org/10.1016/S1146-609X(03)00040-7

BUOSI, P.R.B., PAULETO, G.M., LANSAC-TÔHA, F.A. \& VELHO, L.F.M. 2011. Ciliate community associated with aquatic macrophyte roots: Effects of nutrient enrichment on the community composition and species richness. Eur. J. Protistol. 47:86-102. http://dx.doi.org/10.1016/j. ejop.2011.02.001

CAIRNS JUNIOR, J., McCORMICK, P.V. \& NIEDERLEHNER, B.R. 1993. A proposed framework for developing indicators of ecosystem health. Hydrobiologia. 263(1):1-44. http://dx.doi.org/10.1007/BF00006084

COMPANHIA DE TECNOLOGIA DE SANEAMENTO AMBIENTAL - CETESB. 2001. Relatório de qualidade das águas interiores do estado de São Paulo 2000. CETESB.

COOK, W.L., AHEARN, D.J., REINHARDT, D.J. \& REIBER, R.J. 1974. Blooms of an algophorous amoeba associated with Anabaena in fresh water lake. Water, Air, and Soil Poll. 3:71-80. http://dx.doi.org/10.1007/ BF00282728

CORLISS, J.O. 1979. The ciliated protozoa: characterization, classification and guide to the literature. 2nd ed. Pergamon, New York.

COSTA, D. M., ALVES, G.M., VELHO, L.F.M. \& LANSAC-TÔHA, F.A. 2011. Species richness of testate amoebae in different environments from the upper Paraná river floodplain (PR/MS). Acta Sci. Biol. Sci. 33(3):263-270.

CURDS, C.R. 1969. An illustrated key to the British freshwater ciliated protozoa commonly found in activated sludge. Wat. Pollut. Res. Tech. Paper 12.

DIAS, R.J.P., WIELOCH, A.H. \& D'AGOSTO, M. 2008. The influence of environmental characteristics on the distribution of ciliates (Protozoa, 
Ciliophora) in an urban stream of southeast Brazil. Braz. J. Biol. 68(2):287-295.

DRAGESCO, J. \& DRAGESCO-KERNÉIS, A. 1986. Ciliés libres de l'Afrique intertropicale: introduction a la connaissance et à l'étude des ciliés. Orstom, Paris.

EDMONDSON, W.T. 1959. Freshwater biology. 2nd ed. Wiley, New York.

FOISSNER, W. \& BERGER, H. 1996. A user friendly guide to the ciliates (Protozoa, Ciliophora) commonly used by hydrobiologists as bioindicators in rivers, lakes, and waste waters, with notes on their ecology. Freshwater Biol. 35:375-482.

FOISSNER, W., BLATTERER, H., BERGER, H. \& KOHMANN, F. 1991. Taxonomische und ökologische revision der ciliaten des saprobiensystems- Band I: Cyrtophorida, Oligotrichida, Hypotrichia, Colpodea. Informationsberichte des Bayer. Landesamtes für wasserwirtschaft, München, 1/91.

FOISSNER, W., BERGER, H. \& KOHMANN, F. 1992. Taxonomische und ökologische revision der ciliaten des saprobiensystems- Band II: Peritrichia, Heterotrichida, Odontostomatida.. Informationsberichte des Bayer. Landesamtes für wasserwirtschaft, München, 5/92.

FOISSNER, W., BERGER, H. \& KOHMANN, F. 1994. Taxonomische und ökologische revision der ciliaten des saprobiensystems- Band III: Hymenostomata, Protostomatida, Nassulida. Informationsberichte des Bayer. Landesamtes für wasserwirtschaft, München, 5/92.

FOISSNER, W., BERGER, H., BLATTERER, H. \& KOHMANN, F. 1995. Taxonomische und ökologische revision der ciliaten des saprobiensystemsBand IV: Gymnostomatea, Loxodes, Suctoria. Informationsberichte des Bayer. Landesamtes für wasserwirtschaft, München, 1/95.

FOISSNER, W., BERGER, H. \& SCHAUMBURG, J. 1999. Identification and ecology of limnetic plankton ciliates. Bayerisches Lamdesamt für wasserwirtschaft. Informationsberichte, Munich.

GALBRAITH, L.M. \& BURNS, C.W. 2010. Drivers of ciliate and phytoplankton community structure across a range of water bodies in southern New Zealand. J. Plankton Res. 32:327-339. http://dx.doi. org/10.1093/plankt/fbp134

GILBERT, J.J. 1994. Jumping behavior in the oligotrich ciliates Strobilidium velox and Halteria grandinella and its significance as a defense against rotifer predators. Microb. Ecol. 27:189-200. http://dx.doi.org/10.1007/ BF00165817

GODINHO, M.J.L \& REGALI-SELEGHIM, M.H. 1999. Diversidade de protozoários de vida livre: Protozoa. In Biodiversidade do Estado de São Paulo: Síntese do conhecimento ao final do século XX, 1. Microrganismos e Vírus (V.P. Canhos \& R.F. Vazoller, eds.). FAPESP, São Paulo p. 82-91.

GOLTERMAN, H. L., CLYMO, R. S., OHNSTAD, M.A. 1978. Methods for physical \& chemical analysis of Fresh Water. 2nd. Edition Blackwell Scientific Publications. IBP, n. 8.

GOMES, E.A.T. \& GODINHO, M.J.L. 2003. Structure of the protozooplankton community in a tropical shallow and eutrophic lake in Brazil. Acta Oecol. 24:153-161. http://dx.doi.org/10.1016/S1146-609X(03)00039-0

JACK, J.D. \& GILBERT, J.J. 1997. Effects of Metazoan Predators on Ciliates on Freshwater Plankton Communities. J. Euk. Microbiol. 44(3):194-199. http://dx.doi.org/10.1111/j.1550-7408.1997.tb05699.x

JÜRGENS, K. \& ŠIMEK, K. 2000. Functional response and particle size selection of Halteria cf. grandinella, a common freshwater oligotrichous ciliate. Aquat. Microb. Ecol.. 22:57-68. http://dx.doi.org/10.3354/ ame 022057

KAHL, A. 1930-35. Urtiere oder Protozoa. Wimpertiere oder Ciliata (infusoria). Die Tierwelt Deutschlands. G.Fisher, Jena, parts 18 (1930) 25(1932), 30 (1935).

KOROLEFF, F. 1976. Determination of nutrients. In: Grasshoff, K., ed., Methods of seawater analysis. Verlag Chemie, Weinhein, New York, p.117-181.

KRAINER, K.H. 1991. Contributions to the morphology, infraciliature and ecology of the planktonic ciliates Strombidium pelagicum n.sp. Pelagostrombidium mirabile (Penard, 1916) n.g., n. comb., and Pelagostrombidium fallax (Zacharias, 1896) n.g., n. comb. (Ciliphora,
Oligotrichida). Eur. J. Protistol. 27:60-70. http://dx.doi.org/10.1016/ S0932-4739(11)80428-1

KRATZER, C.R. \& BREZONIK, P.L. 1981. A Carlson-type trophic state index for nitrogen in Florida lakes. Water Resour. Bull. 17(4):713 - 715 . http://dx.doi.org/10.1111/j.1752-1688.1981.tb01282.x

KUDO, R.R. 1977. Protozoology. 5th ed. Charles C. Thomas, Illinois.

LANSAC-TÔHA, F.A, ZIMMERMANN-CALLEGARI, M.C, ALVES, G.M, VELHO, L.F.M \& FULONE, L.J. 2007. Species richness and geographic distribution of testate amoebae (Rhizopoda) in Brazilian freshwater environments. Acta Sci. Biol. Sci. 29(2):185-195.

LAYBOURN-PARRY, J. 1992. Protozoan Plankton Ecology. Chapman and Hall, London.

LAYBOURN-PARRY, J., JONES, K. \& HOLDICH, J.P. 1987. Grazing by Mayorella sp. (Protozoa:Sarcodina) on cyanobacteria. Funct. Ecol. 1:99104. http://dx.doi.org/10.2307/2389711

LAYBOURN-PARRY, J., OLVER, J., ROGERSON, A. \& DUVERGÉ, P.L. 1990. The temporal and spatial patterns of protozooplankton abundance in a eutrophic temperate lake. Hydrobiologia. 203:99-110. http://dx.doi. org/10.1007/BF00005618

LEE, J.J., HUTNER, S.H. \& BOVEE, E.C. 1985. An illustrated guide to the protozoa. Allen Press, Kansas.

LÉVÊQUE, C., BALIAN, E.V. \& MARTENS, K. 2005. An assessment of animal species diversity in continental waters. Hydrobiologia. 542:39-67. http://dx.doi.org/10.1007/s10750-004-5522-7

LYNN, D.H. 2008. The ciliated protozoa: characterization, classification and guide to the literature. 3rd ed. Springer, Dordrecht.

MACKERETH, F.J.H., HERON, J. \& TALLING, J.F. 1978. Water Analysis: Some Revised Methods for Limnologists. Freshwater Biological Association. Scientific Association. Kendall: Titus Wilson \& Son Ltd.

MANSANO, A.S., HISATUGO, K.F., LEITE, M.A., LUZIA, A.P. \& REGALISELEGHIM, M.H. 2013. Seasonal variation of the protozooplanktonic community in a tropical oligotrophic environment (Ilha Solteira reservoir, Brazil). Brazil. Braz. J. Biol. 73(1): page not defined.

MIECZAN, T. 2007. Relationships among ciliated protozoa and water chemistry in small peat-bog reservoirs (Łęczna-Włodawa Lakeland, Eastern Poland). Oceanol. Hydrobiol. St. 36(2):77-86. http://dx.doi. org/10.2478/v10009-007-0014-5

PACE, M.L. \& ORCUTT, JR, J.D. 1981. The relative importance of protozoans, rotifers and crustaceans in a freshwater zooplankton community. Limnol. Oceanogr. 36:822-830. http://dx.doi.org/10.4319/ 10.1981.26.5.0822

PAGE, F.C. 1976. An illustrated key to freshwater and soil amoebae with notes on cultivation and ecology. Freshwater Biological Association Scientific publication $\mathrm{n}^{\circ} 34$. Cumbria.

PAULETO, G.M., VELHO, L.F.M., BUOSI, P.R.B., BRÃO, A.F.S., LANSAC-TÔHA, F.A\& BONECKER, C.C. 2009. Spatial and temporal patterns of ciliate species composition (Protozoa: Ciliophora) in the plankton of the Upper Paraná River floodplain. Braz. J. Biol. 69(2):517 527. http://dx.doi.org/10.1590/S1519-69842009000300007

PENNAK, R.W. 1953. Freshwater invertebrates. Ronald, New York.

R DEVELOPMENT CORE TEAM. 2009. R: A language and environment for statistical computing. R Foundation for Statistical Computing, Vienna, Austria. (http://www.R-project.org).

REGALI-SELEGHIM, M.H. 1992. Flutuações nas comunidades planctônicas e bentônicas de um ecossistema artificial raso (Represa do Monjolinho, São Carlos - SP), com ênfase das populações de protozoários e bactérias. Dissertação de Mestrado, Universidade Federal de São Carlos, São Carlos.

REGALI-SELEGHIM, M.H. 2001. Rede trófica microbiana em um sistema eutrófico raso (Reservatório do Monjolinho, São Carlos - SP) - estrutura e função. Tese de doutorado. Universidade Federal de São Carlos, São Carlos.

REGALI-SELEGHIM, M.H., GODINHO, M.J.L \& MATSUMURATUNDISI, T. unpublished data. Ciliados de vida livre em corpos aquáticos das UGRHI-Mntiqueira, Alto Tietê e Pardo. 
Bagatini, I.L. et al.

REGALI-SELEGHIM, M.H., GODINHO, M.J.L. \& MATSUMURATUNDISI, T. 2011. Checklist dos "protozoários" de água doce do Estado de São Paulo, Brasil. Biota Neotropica. 11(1a): http://www. biotaneotropica.org.br/v11n1a/en/abstract?inventory+bn0141101a2011. (último acesso em 19/07/2012).

ŠIMEK, K., JÜRGENS, K., NEDOMA, J., COMERMA, M. \& ARMENGOL, J. 2000. Ecological role and bacterial grazing of Halteria spp.: small freshwater oligotrichs as dominant pelagic ciliate bacterivores. Aquat. Microb. Ecol. 22:43-56. http://dx.doi.org/10.3354/ame022043

STRICKLAND, J. \& PARSONS, T. 1960. A manual of seawater analysis. Bull. Fish. Res. Board Can. 125:1-185.

TOLEDO JUNIOR, A.P., TALARICO, N., CHINEZ, S.J. \& AGUDO, E.G. 1983. Aplicação de modelos simplificados para a avaliação de processo de eutrofização em lagos e reservatórios tropicais. In Anais $120^{\circ}$ Congresso Brasileiro de Engenharia Sanitária e Ambiental. CETESB, p.1-34.
VALDERRAMA, J.C. 1981. The simultaneous analysis of total nitrogen and phosphorus in natural waters. Mar. Chem. 10:109-122. http://dx.doi. org/10.1016/0304-4203(81)90027-X

VELHO, L.F.M., LANSAC-TÔHA, F.A. \& BINI, L.M. 2003. Influence of environmental heterogeneity on the structure of testate amoebae (Protozoa, Rhizopoda) assemblages in the plankton of the upper Paraná River floodplain, Brazil. Int. Rev. Hydrobiol. 88:154-166. http://dx.doi. org/10.1002/iroh.200390011

VELHO, L.F.M., PEREIRA, D.G., PAGIORO, T.A., SANTOS, V.D., PERENHA, M.C.Z. \& LANSAC-TÔHA, F.A. 2005. Abundance, biomass and size structure of planktonic ciliates in reservoirs with distinct trophic states. Acta Limnol. Bras. 17:361-371.

WEISSE, T. \& FRAHM, A. 2001. Species-specific interactions between small planktonic ciliates (Urotricha spp.) and rotifers (Keratella spp.). J. Plank. Res. 23(12):1329-1338. http://dx.doi.org/10.1093/plankt/23.12.1329 
Appendix 1. Protozoan species list for the 13 water bodies from the UGRHI Mogi-Guaçu. The numbers represent the density (ind.mL ${ }^{-1}$ ) of each taxon and the numbers between brackets represent the number of morphotypes.

\begin{tabular}{|c|c|c|c|c|c|c|c|c|c|c|c|c|c|}
\hline & PML & SGR & BPP & DL & $\mathbf{C P}$ & $\mathbf{P P}$ & DR & ER & PBC & ICL & UL & AML & FAR \\
\hline \multicolumn{14}{|l|}{ Ciliophora } \\
\hline \multicolumn{14}{|l|}{ Intramacronucleata } \\
\hline \multicolumn{14}{|l|}{ Armophorea Lynn, 2004} \\
\hline \multicolumn{14}{|l|}{ Armophorida Jankowksi, 1964} \\
\hline Caenomorpha cf. uniserialis Levander, 1894 & & & & 0.01 & & & & & & & & & \\
\hline \multicolumn{14}{|l|}{ Colpodea Small \& Lynn, 1981} \\
\hline \multicolumn{14}{|l|}{ Bursariomorphida Fernández-Galiano, 1978} \\
\hline Bursaridium pseudobursaria (Faure-Fremiet, 1924) Kahl, 1927 & & & & & & & 0.02 & & & & & & \\
\hline Bursaridium sp & & & 0.03 & & & & & & & & & & \\
\hline \multicolumn{14}{|l|}{ Bryometopida Foissner, 1985} \\
\hline Thylakidium sp Schewiakoff, 1893 & & & 0.03 & 0.03 & & 0.02 & & & & 0.06 & & & \\
\hline \multicolumn{14}{|l|}{ Colpodida de Puytorac et al., 1974} \\
\hline Colpoda sp & & & 0.02 & & & & & & & & & & \\
\hline Maryna sp & & & & & & 0.52 & & & & & & & \\
\hline Mycterothrix sp & & & & & & & & & & 0.21 & & & \\
\hline \multicolumn{14}{|l|}{ Cyrtolophosidida Foissner, 1978} \\
\hline Cyrtolophosis mucicola Stokes, 1885 & & & 0.02 & & & 0.73 & & & & & & & 7.22 \\
\hline Cyrtolophosis sp & & & 0.01 & & & & & & & & & & \\
\hline \multicolumn{14}{|l|}{ Litostomatea Small \& Lynn, 1981} \\
\hline \multicolumn{14}{|l|}{ Haptoria Corliss, 1974} \\
\hline Cyclotrichiida Jankowski, 1980 & & & & & & & & & & & & & \\
\hline Askenasia volvox Kahl, 1930 & & & & & & & 1.31 & & 0.04 & & & & \\
\hline Mesodinium pulex (Claparède \& Lachmann) Stein, 1867 & & & & 0.37 & & & & & & & & & \\
\hline Mesodinium sp & & & & & & 0.08 & 0.08 & & & 0.42 & 0.24 & 0.68 & 42.73 \\
\hline Haptorida Corliss, 1974 (syns. Spathidiida) & & & & & & & & & & & & & \\
\hline Actinobolina sp & & & 0.04 & & & & & & & & & & \\
\hline Chaenea sp & & & 0.02 & & & & & & & & & & \\
\hline Didinium chlorelligerum Kahl, 1935 & & & & & 0.17 & & & & & & & & \\
\hline Didinium sp & & & & 0.02 & & & & & & & & & \\
\hline Enchelydium sp & & & 0.01 & & & & & & & & & & \\
\hline Enchelyodon lasius Stokes, 1885 & & & 0.01 & & & & & & & & & & \\
\hline Enchelyodon sp & & & & & & & & & & & 0.02 & & \\
\hline Enchelys gasterosteus Kahl, 1926 & & & 0.06 & 0.05 & 0.03 & 0.04 & 0.02 & & & 0.17 & & & \\
\hline Enchelys sp & & & 0.03 & & & & & & & & & & \\
\hline Gymnostomatida não identificado & & & & 0.01 & & & & & & & & & \\
\hline Lacrimaria olor (Müller, 1786) Bory, 1924 & & & & 0.02 & & & & & & & & & \\
\hline Lagynophrya sp & & & & & & & & & & 0.13 & & & \\
\hline Monodinium balbianii Fabre-Domergue, 1888 & & & 0.19 & 0.02 & & & & & 0.16 & & & & \\
\hline Paradileptus elephantinus (Svec, 1897) Kahl, 1931 & & & & 0.01 & 0.87 & 0.02 & 0.02 & & 0.12 & & & & \\
\hline Paradileptus sp. & & & & & & & & & & & 0.18 & & \\
\hline Phialina pupula Müller, 1773 & & & & 0.01 & & & & & & & & & \\
\hline Trachelius ovum (Ehrenberg, 1831) Ehrenberg, 1838 & & & & 0.01 & & & & & & & & & \\
\hline Pleurostomatida Schewiakoff, 1896 & & & & & & & & & & & & & \\
\hline Amphileptus pleurosigma (Stokes, 1884) Foissner, 1984 & & & & 0.01 & & & & & & & & & \\
\hline Amphileptus sp & & & & 0.01 & & & & & & & & & \\
\hline Litonotus sp & & & & 0.01 & & & & & & 0.04 & & & \\
\hline Oligohymenophorea de Puytorac et al., 1974 & & & & & & & & & & & & & \\
\hline Hymenostomatia Delage \& Hérouard, 1896 & & & & & & & & & & & & & \\
\hline Glaucoma frontata (Stokes, 1886) Kahl, 1931 & & & & & & & & & & 0.06 & & & \\
\hline Tetrahymena sp & & & 0.01 & & & & & & & & & & \\
\hline Hymenostomatia & & & & 0.01 & & & & & & & & & \\
\hline Peniculia Fauré-Fremiet in Corliss, 1956 & & & & & & & & & & & & & \\
\hline Disematostoma tetraedricum (Faure-Fremiet, 1924) Kahl, 1931 & & & 0.02 & & & & & & & & & & \\
\hline Frontonia leucas (Ehrenberg, 1834) Ehrenberg, 1838 & & & & 0.02 & & & & & & & & & \\
\hline Frontonia sp & & & & & & & & & & 0.03 & & 0.24 & \\
\hline Lembadion cf. bullinum (Müller, 1786) Perty, 1849 & & & & 0.01 & & & & & & & & & \\
\hline Lembadion lucens (Maskell, 1887) Kahl, 1931 & & & & 0.04 & & & 0.05 & & & & & & \\
\hline Lembadion $\mathrm{sp}$ & & & 0.02 & & & & & & & & & & \\
\hline Marituja pelágica Gajewskaja, 1928 & & & & & & 0.06 & & & & & & & \\
\hline Paramecium bursaria (Ehrenberg, 1831) Focke, 1836 & & & 0.34 & & & & & & & & & & \\
\hline Paramecium cf. aurelia-komplex Müller, 1773 & & & & 0.03 & & & & & & & & & \\
\hline Paramecium cf. putrinum Claparède \& Lachmann, 1859 & & & & & 0.02 & & & & & & & & \\
\hline
\end{tabular}


Appendix 1. Continued...

\begin{tabular}{|c|c|c|c|c|c|c|c|c|c|c|c|c|c|}
\hline & PML & SGR & BPP & DL & CP & PP & DR & ER & PBC & ICL & UL & AML & FAR \\
\hline Paramecium putrinum Claparède \& Lachmann, 1859 & & & & 0.02 & & & & & & & & & \\
\hline Paramecium sp & & & 0.04 & & & & 0.03 & & & & & & \\
\hline Stokesia vernalis Wenrich, 1929 & & & & 0.05 & 1.06 & 0.04 & & & & & & & \\
\hline Urocentrum turbo (Müller, 1786) Nitzsch, 1827 & & & 0.04 & 0.07 & & & 0.11 & & & & & & \\
\hline \multicolumn{14}{|l|}{ Peritrichia Stein, 1859} \\
\hline Campanella sp & 0.04 & & & 0.02 & & & & & & 1.51 & 0.49 & & \\
\hline Carchesium pectinatum Zacharias, 1897 & & & & & & 0.24 & 0.19 & & & & & & \\
\hline Carchesium sp & & & & & 0.06 & & & & & & 0.12 & & \\
\hline Epistilys sp & & & & & & & & 0.03 & & & & & \\
\hline Pseudovorticella monilata (Tatem, 1870) Foissner \& Schiffmann, 1974 & & & & & 0.08 & & & & & & & & \\
\hline Telotrochia de Campanella sp & & & & 0.03 & & & & & & & & & \\
\hline Telotrochia de Epistylis sp & & & & 0.01 & & & & & & & & & \\
\hline Telotrochidium sp & & & 0.04 & & & & & & & & & & \\
\hline Trichodina sp & 0.02 & & & & & & & & & & & & \\
\hline Vorticella aquadulcis-komplex & & & & & & & & 0.51 & & & & & \\
\hline Vorticella campanula Ehrenberg, 1831 & & & 0.02 & 0.02 & & & & & & & & & \\
\hline Vorticella mayeri Fauré-Fremiet, 1920 & & & & & & & & & & & & 8.93 & \\
\hline Vorticella spp & 0.46 & 0.04 & 0.16 & $\begin{array}{l}0.03 \\
(3)\end{array}$ & & 0.42 & 0.06 & & 1.68 & & & & \\
\hline Vorticelid & & & & 0.02 & & & & & & & & & \\
\hline \multicolumn{14}{|l|}{ Scuticociliatia Small, 1967} \\
\hline Cinetochilum margaritaceum (Ehrenberg, 1831) Perty, 1849 & 1.14 & 0.85 & 0.31 & 0.34 & 0.72 & 0.84 & 0.06 & & & & & 15.15 & \\
\hline Ctedoctema acanthocryptum Stokes, 1884 & & & & 0.15 & & & & & & & & & \\
\hline Cyclidium $\mathrm{sp}$ & & & & & & 0.06 & & & & & & & \\
\hline Scuticuciliatia & & & & $\begin{array}{l}0.03 \\
(2)\end{array}$ & & & & & & & & & \\
\hline \multicolumn{14}{|l|}{ Phyllopharyngea de Puytorac et al., 1974} \\
\hline \multicolumn{14}{|l|}{ Cyrtophoria Fauré-Fremiet in Corliss, 1956} \\
\hline Chlamydodon sp & & & 0.02 & & & & & & & & & & \\
\hline Pseudochilodonopsis fluviatilis Foissner, 1988 & & & & 0.01 & & & & & & & & & \\
\hline Trithigmostoma srameki Foissner, 1988 & & & & 0.02 & & & & & & & & & \\
\hline Trithigmostoma steini (Blochmann, 1895) Foissner, 1988 & & & & & & & & & 0.02 & & & & \\
\hline \multicolumn{14}{|l|}{ Suctoria Claparède \& Lachmann, 1858} \\
\hline Podophrya sp & & & 0.07 & & & 0.04 & & & & & & & \\
\hline Sphaerophrya magna Maupas, 1881 & & & & 0.01 & & & & & & & & & \\
\hline Staurophrya sp & & & & & & 0.42 & & & & & & & \\
\hline Free-swimming of suctoria & & & & 0.03 & & & & & & & & & \\
\hline \multicolumn{14}{|l|}{ Prostomatea Schewiakoff, 1896} \\
\hline Prorodontida Corliss, 1974 & & & & & & & & & & & & & \\
\hline Balanion sp & & & & & & 0.02 & & & & & & & \\
\hline $\begin{array}{l}\text { Bursellopsis nigricans nigricans (Lauterborn, 1894) Foissner, Berger } \\
\& \text { Schaumburg, } 1999\end{array}$ & & & & 0.01 & & 0.08 & & & & & & & \\
\hline Bursellopsis truncata (Kahl, 1927) Corliss, 1960 & & & & 0.01 & & & & & & & & & \\
\hline Coleps hirtus cf. viridis Ehrenberg, 1831 & & & & 0.05 & & & & & & & & & \\
\hline Coleps sp & 0.27 & & 0.83 & & & 0.27 & 0.07 & & & 0.03 & & 2.17 & \\
\hline Holophrya discolor Ehrenberg, 1834 & 0.05 & & 0.18 & & 0.11 & & & & & & & & \\
\hline Holophrya sp & & & & & & & & & & 0.18 & & & \\
\hline Pelagothrix sp & & & & & & & 0.08 & & & & & & \\
\hline Urotricha armata Kahl, 1927 & 0.02 & & & 0.02 & & & & & & & & & \\
\hline Urotricha cf. agilis Stokes, 1886 & & & 5.54 & 0.03 & & 0.02 & 0.03 & & 1.99 & & & & \\
\hline Urotricha cf. armata Kahl, 1927 & & & & & 0.02 & & & & & & & & \\
\hline Urotricha cf. faurei Dragesco, Iftode \& Fryd-Versavei, 1974 & & & & 0.17 & & & & & & & & & \\
\hline Urotricha globosa Schewiakoff, 1892 & & & & & & & & & 2.1 & 0.21 & & & \\
\hline Urotricha matthesi matthesi Krainer, 1995 & & & & & 0.62 & & & & & & & & \\
\hline Urotricha spp & 0.08 & & 0.1 & & 0.05 & 0.91 & 0.11 & & 0.04 & & 0.3 & & \\
\hline \multicolumn{14}{|l|}{ Spirotrichea Bütschli, 1889} \\
\hline \multicolumn{14}{|l|}{ Choreotrichia Small \& Lynn, 1985} \\
\hline Codonella sp & & & & & & & & & & 1.1 & & & \\
\hline Rimostrombidium caudatum Kahl, 1932 & & & & & & 0.18 & 0.08 & & & & & & \\
\hline Rimostrombidium humile (Penard, 1922) Petz \& Foissner, 1992 & 0.02 & & 0.04 & 0.05 & 1.11 & 0.06 & & & & & & & \\
\hline Rimostrombidium spp & 0.02 & 0.01 & 0.03 & 0.03 & 0.11 & & 0.04 & & 0.1 & & 0.17 & & \\
\hline Tintinnidium cf. semiciliatum Sterki, 1879 & & & & & 2.17 & & & & & & & & \\
\hline Tintinnidium sp & & & & & & & & & & 1.38 & & & \\
\hline Oligotrichia Bütschli, 1887/1889 & & & & & & & & & & & & & \\
\hline
\end{tabular}


Appendix 1. Continued...

\begin{tabular}{|c|c|c|c|c|c|c|c|c|c|c|c|c|c|}
\hline & PML & SGR & BPP & DL & $\mathbf{C P}$ & PP & DR & ER & PBC & ICL & UL & AML & FAR \\
\hline Limnostrombidium cyst & 0.01 & & & & & & & & & & & & \\
\hline Limnostrombidium spp & & & & & & & & & 3.32 & 2.47 & & & \\
\hline Limnostrombidium viride (Stein, 1867) Krainer, 1995 & 0.24 & 0.04 & 1.36 & 0.06 & 1.02 & 0.27 & 0.08 & & & & 0.15 & & \\
\hline \multicolumn{14}{|l|}{ Stichotrichia Small \& Lynn, 1985} \\
\hline Halteria chlorelligera Kahl, 1932 & & 0.03 & & & & & & & & & & & \\
\hline Halteria cirrifera Kahl, 1935 & & & & & & & & & & 8.95 & & & \\
\hline Halteria grandinella (Müller, 1973) Dujardin, 1841 & 1.76 & 4.14 & 4.62 & 0.81 & 3.21 & & & 0.06 & 0.62 & & & & \\
\hline Halteria sp & & & & & & 0.69 & 0.55 & & & & 0.36 & 24.74 & 11.15 \\
\hline Holosticha monilata Kahl, 1928 & & & & 0.01 & & & & & & & & & \\
\hline Hypotrichidium conicum Ilowaisky, 1921 & & & & & & & & & 0.02 & & & & \\
\hline Stichotricha secunda Perty, 1849 & & & & & & 0.02 & 2.33 & & & & & & \\
\hline Stichotricha sp & 0.02 & & 0.17 & 0.05 & & & & & & & & & \\
\hline Strongylidium $\mathrm{sp}$ & & & 0.03 & & & & & & & & & & \\
\hline $\begin{array}{l}\text { Uroleptus cf musculus (Kahl, 1932) Foissner, Blatterer, Berger \& } \\
\text { Kohmann, } 1991\end{array}$ & & & & 0.01 & & & & & & & & & \\
\hline Uroleptus sp & & & & 0.02 & & & 0.02 & & & & & & \\
\hline Stichotrichia not identified & & & $\begin{array}{l}0.33 \\
(3)\end{array}$ & $\begin{array}{l}0.09 \\
(6)\end{array}$ & $\begin{array}{l}0.05 \\
(2)\end{array}$ & & $\begin{array}{l}0.06 \\
(1)\end{array}$ & & & & & & \\
\hline \multicolumn{14}{|l|}{ Postciliodesmatophora Gerassimova \& Seravin, 1976} \\
\hline \multicolumn{14}{|l|}{ Heterotrichea Stein, 1859} \\
\hline \multicolumn{14}{|l|}{ Heterotrichida Stein, 1859} \\
\hline Linostomella vorticella Foissner, Berger \& Schaumburg, 1999 & & & 0.03 & & & & 0.02 & & & & & & \\
\hline Stentor muelleri Ehrenberg, 1832 & & & & & & 0.11 & & & & & & & \\
\hline \multicolumn{14}{|l|}{ Loxodida Jankowski, 1980} \\
\hline Loxodes sp & & & 0.01 & & & 0.02 & & & & 0.04 & & & \\
\hline Ciliophora not identified & $\begin{array}{l}0.01 \\
(1)\end{array}$ & $\begin{array}{l}0.03 \\
(2)\end{array}$ & $\begin{array}{l}0.34 \\
(16)\end{array}$ & $\begin{array}{l}0.14 \\
(8)\end{array}$ & $\begin{array}{l}0.09 \\
(4)\end{array}$ & & & & & & & & \\
\hline \multicolumn{14}{|l|}{ Amoebozoa Lühe, 1913, emend. Cavalier-Smith, 1998} \\
\hline Mayorella bicornifrons Bovee, 1970 & 1.32 & & & & & & & & & & & & \\
\hline Mayorella cf. limacis Bovee, 1970 & 4.03 & & & & & & & & & & & & \\
\hline Arcella vulgaris Ehrenberg, 1830 & & & 0.51 & 0.12 & 0.02 & & 0.02 & & & & & & \\
\hline Arcella sp & & & & & & & & & & 1.81 & & & \\
\hline Thecate amoeba & & 0.01 & & & & & & & & & & & \\
\hline Polychaos timidum Bovee, 1972 & & & & 0.01 & & & & & & & & & \\
\hline Amoeba diminuta Bovee, 1972 & & & 0.08 & & & & & & & & & & \\
\hline \multicolumn{14}{|l|}{ Rhizaria } \\
\hline \multicolumn{14}{|l|}{ Cercozoa Cavalier-Smith, 1998 (insertae sedis) } \\
\hline Pseudodifflugia cf. fascicularis Penard, 1902 & & & & 0.02 & 0.93 & & & & & & & & \\
\hline Pseudodifflugia cf. gracilis Schlumberger, 1845 & & & & 0.03 & & & & & & & & & \\
\hline Pseudodifflugia sp & & 0.05 & & & & 0.06 & & & & & 28.65 & & 23.83 \\
\hline Naked amoeboid & $0.4(6)$ & $\begin{array}{l}0.09 \\
(6)\end{array}$ & $\begin{array}{l}0.26 \\
(12)\end{array}$ & $\begin{array}{l}0.03 \\
(3)\end{array}$ & & $\begin{array}{l}4.24 \\
\text { (1) }\end{array}$ & & & & & & & \\
\hline \multicolumn{14}{|l|}{ Eukaryota (insertae sedis) } \\
\hline \multicolumn{14}{|l|}{ Centrohelida Kühn, 1926} \\
\hline Sphaerastrum fockei West, 1901 & & & & & 0.03 & & & & & & & & \\
\hline Astrodisculus radians Stern, 1924 & & & & & 0.02 & & & & & & & & \\
\hline
\end{tabular}

